\title{
ANALYSIS OF THE FINANCIAL POSITION OF ENTERPRISES IN PRIVATIZATION IN THE AGRICULTURAL SECTOR IN SERBIA
}

\author{
Predrag Vukadinović, Slavoljub Vujović2 ${ }^{2}$ Boško Vojnović3 \\ *Corresponding authorE-mail: kelovic1967@yahoo.com
}

A R T I C L E I N F O
Original Article
Received: 11 May 2018
Accepted: 23 July 2018
doi:10.5937/ekoPolj1803955V
UDC 658.1+332.025.28]:338.43(497.11)

Keywords:

agriculture, privatization, financial position, analysis, cash flow.

JEL: Q14, G33, D22

\section{A B S T R A C T}

Privatization as a phase of the transitional process also included agriculture. The most attractive enterprises in agriculture, primarily in the food industry, were privatized in the first wave, while the process of privatization of other less attractive companies was slowed down and implemented mainly by the auction model. The remaining companies waiting for the privatization process are not attractive and there are problems that are expressed through poor financial position and relatively low potential. An exception is made by PKB Corporation, which has a potential and relatively stable market, making this company an acceptable option for investors. The financial position of the companies that are ready for privatization at this moment and which is one of the factors of negative influence on the decision of the investor was analyzed using the Altman Z'-score model, the Kralicek Quick test and the balanced growth model. All tests have shown that the analyzed companies are in a bad financial position and that the future investor will have to invest significant funds in financial consolidation, balancing cash flows and investment in order to ensure adequate development and efficient business.

(C) 2018 EA. All rights reserved.

\section{Introduction}

The privatization process in Serbia is perhaps the most important stage in the transition of the economic system to a free market system. This process encompassed all branches of the economic system and thus agriculture. This branch of economy is assessed in literature, research and practice as insufficiently developed with significant structural problems, economically underdeveloped, in the foreign market inadequately competitive, and companies in this branch are largely financially helpless. Privatization

1 Predrag Vukadinović, PhD, Associate professor, Singidunum University, Danijelova Street no. 32, 11000 Belgrade, Serbia, Phone: +381 11309 3741, E-mail: pvukadinovic@singidunum.ac.rs,

2 Slavoljub Vujović, PhD, Senior research associate, Economic institute, Kralja Milana Street no. 16, 11000, Belgrade, Serbia, kelovic1967@yahoo.com, ORCID-ID (https://orcid. org/0000-0002-0686-3486).

3 Boško Vojnović, PhD, Full Professor, High School of Agriculture, Vojvode Putnika Street, no. 56, 15000 Šabac, Serbia, Phone: +381 15344 580, E-mail: bosko_v@mts.rs 
of enterprises in agriculture was first carried out in activities that were otherwise attractive before privatization, so after the wave of privatization companies remained in great difficulty with the uncertain result of privatization. Large agro-industrial conglomerates are largely fragmented, with the result that attractive segments are retained and a large number of workers have lost their jobs. With the abolition of the Privatization Agency, the powers of the exit agency have been transferred to the Ministry of Economy that manages the privatization procedures. Table 1 shows the list of privatization companies in the field of agriculture with current status. On the list, there are 10 companies, of which in four cases there is a possibility of publishing a public call, in one case, activities related to the pre-preparation of the reorganization plan are in progress, after which it will be possible to announce a public call, while for the other five companies, because of the issues that need to be resolved. This paper analyzes the financial position of those companies for which the publication of a public invitation is possible. The analysis does not cover companies for which a public call can not be announced and two companies that are micro levels with insignificant financial indicators. Enterprises that are included in the analysis are: PKB Corporation ad, Padinska Skela, Backa ad, Sivac and Plantaza doo, Velika Drenova. The sample was analyzed by Backa ad, Sivac, for which activities related to the pre-prepared reorganization plan are in progress because they are not in question the legal obstacles in the foreground and the analysis of the financial position of this company shows the justification of the procedure in which it is currently in place. The aim of the analysis is to show the financial position of the company that will be privatized by pointing to the problematic elements of the financial position that will certainly influence the decision of future investors how much will be interested in the privatization of these companies. The problematic of the financial position of these enterprises is a reflection of the economic position of agriculture as an economic branch, so no attractive results are expected. The elements of the financial position of these companies will point to the potential future directions of restructuring the financial, organizational and technical structure of these companies. This analysis will show the problems of the agro-industrial sector as the subject of the analysis is the last large agricultural conglomerate such as PKB Belgrade.

Table 1. Companies and their status in relation to the privatization process

\begin{tabular}{|l|l|l|}
\hline & \multicolumn{1}{|c|}{ Company } & \multicolumn{1}{c|}{ Status } \\
\hline 1. & Jadran a.d., Nova Gajdobra & $\begin{array}{l}\text { Public announcement is not possible, } \\
\text { privatization is possible after the sale/ } \\
\text { cancellation of own shares }\end{array}$ \\
\hline 2. & Airport Agricultural Operations Ltd., Belgrade & $\begin{array}{l}\text { It is not possible to publish a public invitation } \\
\text { - during the realization of the conclusion of } \\
\text { the Government of the Republic of Serbia }\end{array}$ \\
\hline 3. & Backa a.d., Sivac & $\begin{array}{l}\text { During the activities related to the pre- } \\
\text { prepared reorganization plan }\end{array}$ \\
\hline 4. & Branko Gleđa dp, Zrenjanin & Bankruptcy \\
\hline 5. & Omoljica a.d., Omoljica & $\begin{array}{l}\text { Public invitation not possible - there are } \\
\text { requests for restitution }\end{array}$ \\
\hline
\end{tabular}




\begin{tabular}{|l|l|l|}
\hline & \multicolumn{1}{|c|}{ Company } & \multicolumn{1}{c|}{ Status } \\
\hline 6. & PKB Korporacija a.d., Padinska Skela & $\begin{array}{l}\text { Possible announcement of the public } \\
\text { invitation - the most optimal privatization } \\
\text { model is under consideration }\end{array}$ \\
\hline 7. & Plantaza d.o.o., Velika Drenova & Possible public call announcement \\
\hline 8. & Ribarsko gazdinstvo a.d., Beograd & $\begin{array}{l}\text { Public invitation not possible - there are } \\
\text { requests for restitution }\end{array}$ \\
\hline 9. & Simpo Vlasina d.o.o., Vranje & Public invitation-privatization \\
\hline 10. & Simpo Cvece d.o.o., Vranjska Banja & Public invitation-privatization \\
\hline
\end{tabular}

In the analysis of the financial position of these companies, the Altman Z'-score model, the Kralicek's Quick test and the balanced growth model.

\section{Materials and literature review}

The privatization process in Serbia started in 1989 by passing regulations that regulated this area in various ways and through different models. Starting from January 30,2002 , when intensive privatization began, as of July 28, 2009, it was privatized in the activities of agriculture, forestry and water management, by the auction method of 126 companies with a total of 13,341 employees, and by the method of tendering 10 companies with a total of 6630 employees (Zdravković et al., 2010). The privatization process did not proceed as expected. In fact, it can be concluded that this process had even negative effects. By 2011, 153 agricultural enterprises and combines were sold for about 280 million euros, after which 38 contracts were terminated (Vehapi and Šabotić, 2015). Agriculture is in second place in the number of jobs lost. About 65,000 people lost their jobs. Privatization as a socio-economic process should also aim to solve accumulated multi-annual agrarian problems. According to (Pejanović. $2005,210)$, the agrarian problem is the totality of the economic and social problems that arise in the society due to changes that are happening or will happen. The author expresses the opinion that the current course of agriculture transition has not solved the agrarian problem in our country, but has intensified it and it is becoming more and more intense. (Mihailović et al., 2013). The necessity of privatization is a position that is presented as one of the conditions of adjustment to global economic changes. Global changes in the agrarian sector require the liberalization of the market and the change in the ownership structure of the company (Bogavac-Cvetković et al., 2010). The existing agrarian structure is not the cause of the situation in Serbian agriculture, but rather the result of an inadequate long-term relationship with agriculture. Foreign investments are not interested in small holdings and the Law on Agricultural Land is perceived as an obstacle to investment (Jelić, Jovanović, 2010). Estimates of the state of agriculture in Serbia are not optimistic. The crisis in agriculture in Serbia lasts for a long period of time, and the development of agriculture contains chronic problems caused by the absence of systemic and continuous measures of economic policy (Pejanović, 2009). The development of agriculture is related to foreign direct investments and the development of other activities. In the food industry, foreign direct investments are present 
in those activities that were attractive even before privatization. However, foreign direct investment in primary agricultural production is very modest. According to Kapor (2009), the reasons for this investment treatment of agriculture are the exposure of these investments to higher investment risks in other areas due to the impact of weather, climate, infrastructure shortages and land and human resources management. Changes are necessary. According to Pejanović and Tica, 2004, the former socialist company is in its disadvantage, abandoned, obscene, obsolete, bulky, overworked, indebted, insolvent, insolvent and incompetent for any competitive struggle in the foreign market. It is necessary to restructure and privatize it, or vice versa. In the current course of privatization, according to Aničić et al. (2016) were first privatized successful companies. For example, the investment fund "Salford" controls $60 \%$ of domestic dairies, and successful companies in the production of sugar, beer, water planners, etc. have been sold. According to the mentioned authors, nobody paid attention to what should be sold and the capital increase as one of the best privatization solutions failed. During this time, the solvency of the companies is not at a satisfactory level. According to Pejanović et al. (2006) Transition Reforms in Agriculture did not give the expected positive effects or how the authors cited the effects are modest. In support of this paragraph, it is pointed out that the crisis in agriculture is not overcome, while in some segments it has been deepened and there has been no change in the economic situation of agriculture at the macro level, while at the micro level there has been no restructuring of economic entities in the agri-economy. In the presentations, the prevailing view is that agriculture was neglected and that the problems of structural and economic nature were caused by the neglect of systematic and economic solutions that would have an incentive character. The financial performance of the agro-industrial sector is not good. The estimates were presented in a survey conducted by Đuričin and Beraha (2014). The results of the survey showed a poor yield in the agro-industrial sector, $40 \%$ of the analyzed companies have a value of financial power below average, and $40 \%$ of enterprises in the structure have the dominant borrowed funding sources. Agriculture and its related activities will suffer great effects of association in the context of the protection system (Petrović et al., 2006), as it will share a system that provides less protection than it is today. This will generate greater exposure to competition in the EU internal market.

\section{Methodology}

Starting from the main goal of this paper to determine and show the financial position of companies in the privatization process in Serbia, we consider it to be the most adequate Altman Z'-score model. Altman's original Z-score model (Altman, 1968) developed and eventually came to various forms of this model (see Altman 1983; Altman, 2005). This model was applied in various case studies in Serbia (Jakovčević and Andrašević, 2011; Begović et al., 2014, Kuč 2015, Lončarević 2015, Muminović et al., 2011). In addition to this model, we also applied the Kraličekov Quck test as well as the model of balanced growth (Walch, 2003) Below is a more detailed overview of the economicstatistical models we used in the analysis of the selected companies. 
The original Altman Z-score model emerged as a model for predicting bankruptcy in developed financial markets. The original Z-score model contains five financial indicators on the basis of which the financial situation of the company is interpreted.

$\mathrm{Z}$-score is calculated based on the following formula:

$\mathrm{Z}=1.2 \cdot \mathrm{X} 1+1.4 \cdot \mathrm{X} 2+3.3 \cdot \mathrm{X} 3+0.6 \cdot \mathrm{X} 4+1.0 \cdot \mathrm{X} 5$

The above symbols in the discriminatory function have the following meaning:

$\mathrm{Z}=$ the overall index, which referred Z-score;

$\mathrm{X} 1=$ working capital $/$ total assets

$\mathrm{X} 2$ = retained earnings / total assets

$\mathrm{X} 3$ = earnings before interest and taxes / total assets

$\mathrm{X} 4$ = market value equity / book value of total debt

$\mathrm{X} 5=$ sales / total assets.

This model was not applicable to companies operating in developing markets, so Altman modified the original model. The model is adapted to the business environment in emerging markets by introducing a change in indicator X4. Instead of the market value of equity, it is the book value of capital. In addition to this change, the indicator's weights have also been changed, so the new Z'-score model has changed the shape into a new function as shown:

$\mathrm{Z}^{`}=0.717 \cdot \mathrm{X} 1+0.847 \cdot \mathrm{X} 2+3.107 \cdot \mathrm{X} 3+0.420 \cdot \mathrm{X} 4+0.998 \cdot \mathrm{X} 5$

The limit values of the original model have also been changed. Companies successfully operate in a safe zone if the value of Z'-score is greater than 2.90, and companies with a value of 1.23 operate in a distress zone where the likelihood of bankruptcy is high. Between the limit values of 1.23-2.90 there is a gray zone in which businesses threaten bankruptcy but have the chance to improve their business. For the calculation of $Z$ 'score data from the public financial reports of analyzed companies from the database of the Serbian Business Registers Agency (SBRA).

The Klaricek Quick Test was developed in 1990 and provides the opportunity to quickly assess the company's insolvency. This estimate is based on the calculation of four indicators, the two indicators of financial stability and two profitability indicators (Didenko et al, 2012). The test includes the area of financing as the potential of enterprises and income as a way of using potentials. Based on the results of the test, an area for which a more comprehensive analysis of the problem is needed for timely corrective influence is determined (Jakovčević, Andrašić, 2011, 188). The areas to be assessed are the level of self-financing, the duration of the debt repayment, the percentage of Cash Flow in revenue and the viability of the funds. Depending on the obtained values of the components of the model, a certain number of points from 1 to 5 is assigned, which also signifies the quality of the company's financial standing. The companies with a healthy financial standing are rated at 1 or 2 points, 3 points indicate the boundary between good and bad financial position, 4 points expressing a bad financial situation and 5 points poses the risk of insolvency or the threat of bankruptcy (Kubenka, 2016). The average result for financial stability is calculated on the basis of the points obtained from the first two components 
of the model, and the average results for profitability based on the calculated points of the third and fourth components (Kozjak, 2014). The final result is obtained as the arithmetic mean of the previously calculated average values of the indicators expressed in points as shown in Table 2.

Table 2. Evaluation of the components of the Quick-Test

\begin{tabular}{|l|l|l|l|l|l|}
\hline \multicolumn{1}{|c|}{ Indikatori } & \multicolumn{1}{|c|}{$\begin{array}{c}\mathbf{1} \\
\text { Excelent }\end{array}$} & \multicolumn{1}{|c|}{$\begin{array}{c}\mathbf{2} \\
\text { Very good }\end{array}$} & \multicolumn{1}{|c|}{$\begin{array}{c}\mathbf{3} \\
\text { Good }\end{array}$} & $\begin{array}{c}\mathbf{4} \\
\text { Bad } \\
\text { Risk of } \\
\text { Insolvency }\end{array}$ \\
\hline $\mathrm{X}_{1}$ & $>30 \%$ & $>20 \%$ & $>10 \%$ & $<10 \%$ & Negative \\
\hline $\mathrm{X}_{2}$ & $<3$ years & $<5$ years & $<10$ years & $<12$ years & $>30$ years \\
\hline$\left(\mathrm{X}_{1}+\mathrm{X}_{2}\right) / 2$ Finanancial stability & $>12 \%$ & $>8 \%$ & $<8 \%$ & negative \\
\hline $\mathrm{X}_{3}$ & $>15 \%$ & $>5 \%$ & $<5 \%$ & Negative \\
\hline $\mathrm{X}_{4}$ & $>10 \%$ & & \\
\hline$\left(\mathrm{X}_{3}+\mathrm{X}_{4}\right) / 2$ & $>8 \%$ & \\
\hline$\left[\left(\mathrm{X}_{1}+\mathrm{X}_{2}\right) / 2+\left(\mathrm{X}_{3}+\mathrm{X}_{4}\right) / 2\right] / 2$ &
\end{tabular}

Source: Kraliček, http://www.kralicek.at/pdf/qr_druck.pdf, customized by the authors

The indicators of the Kralicek Quick Test are calculated according to the following formulas (Alihodzic, 2013):

- X1 (Own financing coefficient) is calculated as the ratio of equity / total liabilities and shows the share of capital in total sources of financing. The recommended value of this indicator is $10 \%$ or more;

- X2 (Time of debt repayment in years) is calculated as total liabilities-cash / (net profit + amortization) and shows the time of repayment of debt. It is recommended that the value of this indicator be 12 years and less;

- X3 is calculated as the ratio of EBIT / total assets and shows the profitability of total assets in relation to operating profit. The recommended value of this indicator is $8 \%$ or more;

- X4 is calculated as ratio (net profit + amortization) /bussines earnings and shows the share of cash flow in operating income. The recommended value is $5 \%$ or higher.

Growth equilibrium model according to (Walsh, 2003) is used to identify the growth rate that a company can withstand the operational cash flow. This means that the cash flow is in balance if it does not lead to surplus or deficit as a result of growth. The balance of Walsh is marked with $E$ and emphasizes that when $E=1$ the cash flow is neutral, the value $\mathrm{E}>1$ indicates a positive cash flow and $\mathrm{E}<1$ to a negative cash flow. The company is in a position of balanced growth at the value $E=1$. The equilibrium indicator $\mathrm{E}$ is calculated according to the following formula:

$$
\mathrm{E}=\frac{\mathrm{R}}{\mathrm{G} * \mathrm{~T}}=\frac{\mathrm{RE} / \mathrm{S}}{\left[\left(\mathrm{S}_{1} / \mathrm{S}_{0}\right)-1\right] * \mathrm{CA} / \mathrm{S}}
$$


In this formula, symbols and expressions have the following meanings:

E- Equilibrium growth coefficient;

R- Relationship Retained Earnings (RE) and Sales (S): RE / S;

G- Growth rate: (S1 / S0) -1;

S1- Sales of the current year;

S0- Sales previous year;

T- Relationship Current Assets (CA) and Sales (S): CA / S

\section{Results and discussion}

This section presents the results showing the financial position of the company using the Z'-score model, the financial stability and profitability indicators of the Kralicek Quick Test Model and the Balanced Growth model. All obtained results are calculated by the author. Due to a more transparent presentation of the results of the companies PKB Corporation a.d., Padinska Skela will be marked with the letter (A), Backa a.d., Sivac letter (B) and Plantaža doo, Velika Drenova letter (C).

The analyzed period of three years is conditioned by the official change in the form of the financial statements (starting from 2014) but sufficiently representative of the financial position based on the change in the analyzed Z'-score values. These changes as well as the financial position of the companies in the sample are shown in Table 3.

Table 3. The values of Z'-score and Zones of Discrimination

\begin{tabular}{|c|c|c|c|c|c|c|}
\hline \multirow{3}{*}{ Year } & \multicolumn{6}{|c|}{ Company } \\
\hline & \multicolumn{2}{|r|}{$\bar{A}$} & \multicolumn{2}{|r|}{ B } & \multicolumn{2}{|r|}{$\mathrm{C}$} \\
\hline & Z'-score & Zone & Z'-score & Zone & Z'-score & Zone \\
\hline 2014 & 1.62 & Grey & 0.69 & Distress & 1.70 & Grey \\
\hline 2015 & 2.97 & Safe & 0.56 & Distress & 2.30 & Grey \\
\hline 2016 & 2.60 & Grey & 0.60 & Distress & 1.71 & Grey \\
\hline Averige & \multicolumn{2}{|l|}{ A } & \multicolumn{2}{|l|}{ B } & \multicolumn{2}{|l|}{$\mathrm{C}$} \\
\hline Z'-score & \multicolumn{2}{|l|}{2.40} & \multicolumn{2}{|l|}{0.62} & \multicolumn{2}{|l|}{1.90} \\
\hline Zone & \multicolumn{2}{|l|}{ Grey } & \multicolumn{2}{|l|}{ Distress } & \multicolumn{2}{|l|}{ Grey } \\
\hline
\end{tabular}

The shown Z'-score changes indicate the financial position of the companies in the analyzed period and whether it is repaired or worsened. Based on the analysis of these changes, their future financial position can be predicted in relation to the threat of bankruptcy.

The increase in Z's score from 1.62 in 2014 to 2.97 in 2015 suggests that in 2015 there was an improvement in the financial position compared to 2014 and that the company went out of the gray zone into a safe zone of business. In the next 2016, the Z'-score will decrease from 2.97 in 2015 to 2.60 in 2016. The worsening of A's financial position in 2016 coincides with the return of A from safe zone to the gray business zone. The 
average Z'-score for the analyzed period is 2.40 which makes this company position in the gray zone. This position does not mean an automatic and a bad position. The location in the gray zone means that it is possible to make certain changes in the business to the company in a safe zone, which was shown in 2015 compared to 2014. Company B is continuously throughout the analyzed period in the Distress zone. The Z'-score value is constantly less than 1.23, indicating a very bad financial position and a high risk of bankruptcy. The average value of the Z'-score for the analyzed period is 0.62 which puts this company in a distress zone of business without great looks for a significant improvement in its financial position. Score C's score C shows that this company improved its position in 2015 compared to 2014 as the Z'-score in 2015 rose from 1.70 in 2014 to 2.30 in 2015. This improvement in the financial position did not continue in 2016 There has been deterioration and return to level 2014, which is certainly not an encouraging move. Throughout the analyzed period, this company is positioned in the gray zone with already introduced changes within the zone of its operations. The average Z'-score for the analyzed period is 1.90 which keeps this company in the gray business zone. The analyzed changes are shown on Grapf 1.

Figure 1. Dynamics of Z'-score companies in the sample

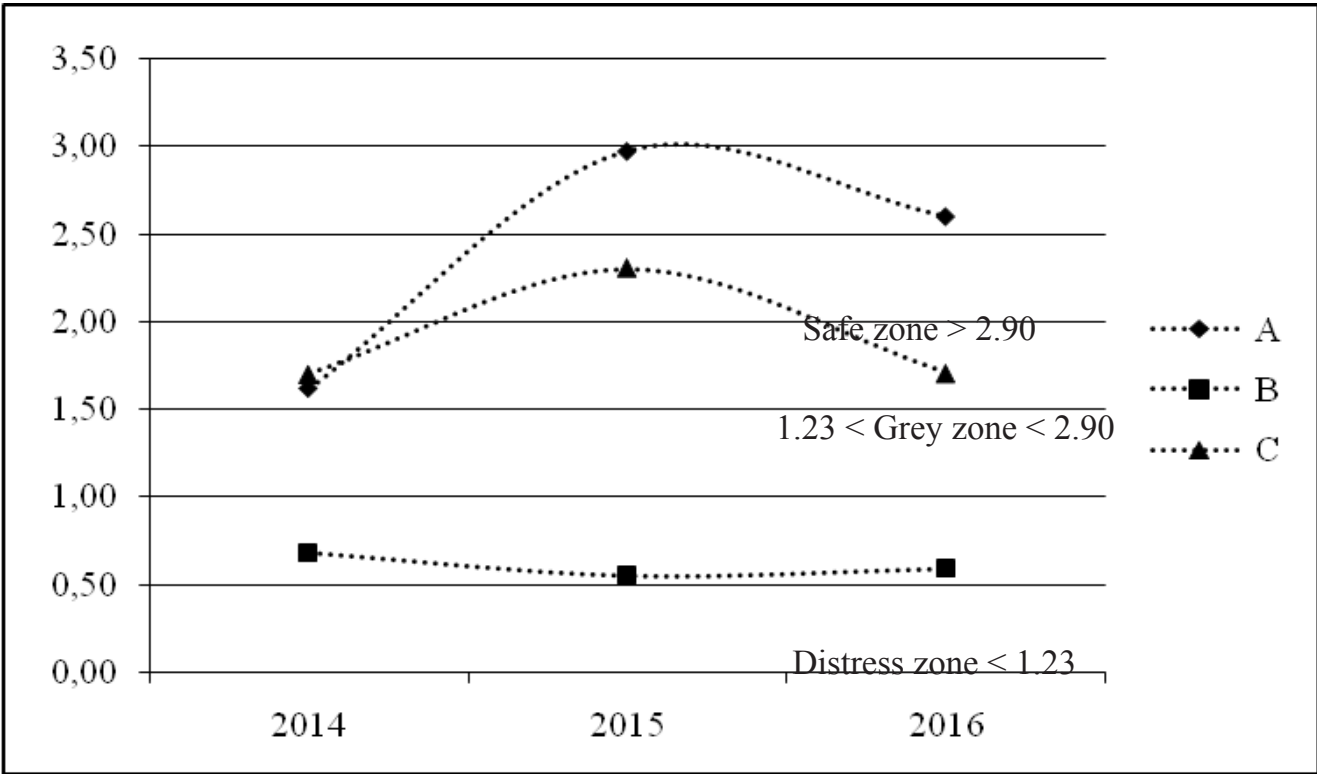

Using the analysis of the indicators of the Kralicek`s Quick test, the financial stability and profitability of companies A was analyzed; B; and C and their overall financial position on the basis of the examination of the action are indicated by two segments. U Table 4; Figures 5 and 6 show the results of the analysis using this model. For a more transparent table, we introduced the following symbols: E (Exscellent), VG (Very Good), G (Good), B (Bad) and RI (Risk of Insolvency). 
Table 4: Calculation of the Klaricek`s Queen's Indicator for company A

\begin{tabular}{|c|c|c|c|}
\hline \multirow{2}{*}{ Indicator } & \multicolumn{3}{|c|}{$\mathbf{A}$} \\
\hline & 2014 & 2015 & 2016 \\
\hline $\mathrm{X} 1$ & 0.69 & 0.82 & 0.80 \\
\hline $\mathrm{X} 2$ & 11.71 & -15.71 & -21.69 \\
\hline $\mathrm{X} 3$ & 0.01 & -0.01 & 0.00 \\
\hline \multirow[t]{2}{*}{$\mathrm{X} 4$} & 0.12 & -0.10 & -0.08 \\
\hline & \multicolumn{3}{|l|}{ Point } \\
\hline $\mathrm{P} 1_{\mathrm{X} 1}$ & 1 & 1 & 1 \\
\hline $\mathrm{P} 2_{\mathrm{X} 2}$ & 3 & 5 & 5 \\
\hline Averige $\left(\mathrm{P} 1_{\mathrm{X} 1+} \mathrm{P} 2_{\mathrm{x} 2}\right) / 2$ & 2 & 3 & 3 \\
\hline Financial stability & VG & $\mathrm{G}$ & G \\
\hline $\mathrm{P} 3_{\mathrm{X} 3}$ & 4 & 5 & 5 \\
\hline $\mathrm{P} 4_{\mathrm{X} 4}$ & 3 & 5 & 5 \\
\hline Averige $\left(\mathrm{P} 3_{\mathrm{X} 3+} \mathrm{P} 4_{\mathrm{X} 4}\right) / 2$ & 3.5 & 5 & 5 \\
\hline Profitability & G & RI & RI \\
\hline Score & 2.75 & 4 & 4 \\
\hline Pozition & $\mathrm{G}$ & $\mathrm{B}$ & B \\
\hline
\end{tabular}

The coefficient of own financing of company A in the analyzed period shows that from the standpoint of own financing this company does not have a risk of insolvency. This indicator (X1) has been excellent in all three years analyzed. In relation to the recommended values $(\leq 12)$, the indicator (X2), only 2014 was within the limits of the recommendation. The negative sign is due to the higher value of the loss (negative business result) than the amount of depreciation. Values obtained outside the recommended values indicate solvency problems. The average value of these two indicators is the basis for assessing the financial stability of the company $(\mathrm{P} 1 \mathrm{x} 1+\mathrm{P} 2 \times 2)$ /2. Based on the values obtained in the analyzed period, it can be concluded that this company has good financial stability but the negative business result in the last two years of the analyzed period is higher than the depreciation. If this trend continues, the company will be exposed to problems of insolvency. Profitability ratios (X3) is extremely low or negative. In all years of the analyzed period, the profitability rate was less than the recommended $(\geq 8 \%)$. The share of cash flow in business revenues (X4) was positive in 2014 and amounted to $12 \%$, which is more than the recommended size ( $\geq 5 \%$ ). In other years, in 2015 and 2016 the value of this indicator was negative because the amount of the negative net result was higher than the amount of depreciation. In the last two years of the analyzed period, the company is at risk of insolvency. The final rating of company A in 2014 was 2.75 points (good), in 2015 it was 4 points (bad) and in 2016 also 4 points (bad). The company is in poor financial condition. 
Table 5. Calculation of the Klaricek`s Quick Test for company B

\begin{tabular}{|c|c|c|c|}
\hline \multirow{2}{*}{ Indicator } & \multicolumn{3}{|c|}{ B } \\
\cline { 2 - 4 } & $\mathbf{2 0 1 4}$ & $\mathbf{2 0 1 5}$ & $\mathbf{2 0 1 6}$ \\
\hline $\mathrm{X} 1$ & 0.50 & 0.55 & 0.52 \\
\hline $\mathrm{X} 2$ & -8.80 & -0.67 & -20.94 \\
\hline $\mathrm{X} 3$ & 0.00 & -0.04 & -0.02 \\
\hline $\mathrm{X} 4$ & -0.39 & -0.82 & -0.16 \\
\hline & & Point & 1 \\
\hline $\mathrm{P} 1_{\mathrm{X} 1}$ & 1 & 5 \\
\hline $\left.\mathrm{P} 2_{\mathrm{X} 2} \mathrm{P} 2_{\mathrm{X} 2}\right) / 2$ & 5 & 5 & 3 \\
\hline Averige $\left(\mathrm{P} 1_{\mathrm{X} 1+}\right.$ & 3 & $\mathrm{G}$ \\
\hline Financial stability & 3 & $\mathrm{G}$ & 5 \\
\hline $\mathrm{P} 3_{\mathrm{X} 3}$ & $\mathrm{G}$ & 5 & 5 \\
\hline $\mathrm{P} 4_{\mathrm{X} 4}$ & 4 & 5 & 5 \\
\hline Averige $\left(\mathrm{P} 3_{\mathrm{X} 3+} \mathrm{P} 4{ }_{\mathrm{X} 4}\right) / 2$ & 5 & 5 & $\mathrm{RI}$ \\
\hline Profitability & 4.5 & $\mathrm{RI}$ & 4 \\
\hline Score & $\mathrm{RI}$ & 4 & $\mathrm{~B}$ \\
\hline Pozition & 3.75 & $\mathrm{~B}$ & $\mathrm{~B}$ \\
\hline
\end{tabular}

Company B does not have a risk of insolvency from the home of the self-financing coefficient. This estimate is based on the value of the self-financing coefficients in the analyzed period. In all years of the analyzed period the coefficients were higher than the recommended value $(\geq 10)$. The repayment period with negative signage indicates that the company is not able to repay due to the negative cash flow. The financial position assessed as good should however be accepted conditionally, primarily as a ratio of own sources of financing and total liabilities, however, a negligible amount of cash (except for 2015) and a negative cash flow nevertheless indicate a risk of insolvency. In 2014, the profitability rate was rated 4 points (bad) because it was less than the recommended $(\geq 8 \%)$, while in 2015 and 2016, a score of 5 points (risk of insolvency) was obtained. The cash flow in the operating income over the three years of the analyzed period was with a negative sign, which was estimated at 5 points (risk of insolvency). The final status of the company the company's quick test in all three years is bad because the number of points ranges from 3.75 in 2014 to 4 in 2015 and 2016. The financial position of this company is poor.

Table 6. Calculation of the Klaricek`s Quick Test for Company C

\begin{tabular}{|c|c|c|c|}
\hline \multirow{2}{*}{ Indicator } & \multicolumn{3}{|c|}{$\mathbf{C}$} \\
\cline { 2 - 4 } & $\mathbf{2 0 1 4}$ & $\mathbf{2 0 1 5}$ & $\mathbf{2 0 1 6}$ \\
\hline $\mathrm{X} 1$ & 0.81 & 0.86 & 0.83 \\
\hline $\mathrm{X} 2$ & -29.06 & -1.10 & -4.24 \\
\hline $\mathrm{X} 3$ & -0.05 & -0.07 & -0.09 \\
\hline $\mathrm{X} 4$ & -0.13 & -2.46 & -0.88 \\
\hline
\end{tabular}




\begin{tabular}{|c|c|c|c|}
\hline \multirow{2}{*}{ Indicator } & \multicolumn{3}{|c|}{ C } \\
\cline { 2 - 4 } & $\mathbf{2 0 1 4}$ & $\mathbf{2 0 1 5}$ & $\mathbf{2 0 1 6}$ \\
\hline & & Point & 1 \\
\hline $\mathrm{P} 1_{\mathrm{X} 1}$ & 1 & 1 & 5 \\
\hline $\mathrm{P} 2_{\mathrm{X} 2}$ & 5 & 5 & 3 \\
\hline Averige $\left(\mathrm{P} 1_{\mathrm{X} 1} \mathrm{P} 2_{\mathrm{X} 2}\right) / 2$ & 3 & $\mathrm{G}$ & $\mathrm{G}$ \\
\hline Financial stability & $\mathrm{G}$ & 5 & 5 \\
\hline $\mathrm{P} 3_{\mathrm{X} 3}$ & 5 & 5 & 5 \\
\hline $\mathrm{P} 4_{\mathrm{X} 4}$ & 5 & 5 & 5 \\
\hline Averige $\left(\mathrm{P} 3_{\mathrm{X} 3+} \mathrm{P} 4_{\mathrm{X} 4}\right) / 2$ & 5 & $\mathrm{RI}$ & $\mathrm{RI}$ \\
\hline Profitability & $\mathrm{RI}$ & 4 & 4 \\
\hline Score & 4 & $\mathrm{~B}$ & $\mathrm{~B}$ \\
\hline Pozition & $\mathrm{B}$ & & \\
\hline
\end{tabular}

Coefficients of C company's financing in the analyzed receive 1 point (excelent). The debt repayment period is in all years of analysis with a negative sign, which means that the company is unable to repay the debts it has. These indicators have received 5 points (risk of insolvency). Financial stability is rated as good because the average value of the indicators $\mathrm{X} 1$ and $\mathrm{X} 2$ is 3 points. The structure of the sources of financing is a good but negative cash flow, however, indicates long-term insolvency risks, so that indicator X1 and its impact on a good financial stability assessment ( 3 points) must be taken with reserve. Coefficients that indicate profitability are negative throughout the analyzed period and are estimated at 5 points (risk of insolvency). The share of cash flow in operating income is also negative throughout the analyzed period and ranges from -0.13 in 2014 to -2.46 in 2015 to -0.88 in 2016 . The cause of these (negative) values is the negative cash flow. The perfect score for this company is 4 point (bad) in all years of the analyzed period. The financial position of this company is bad.

Figure 2. Dynamics of Kralicek's Quick test companies in the sample

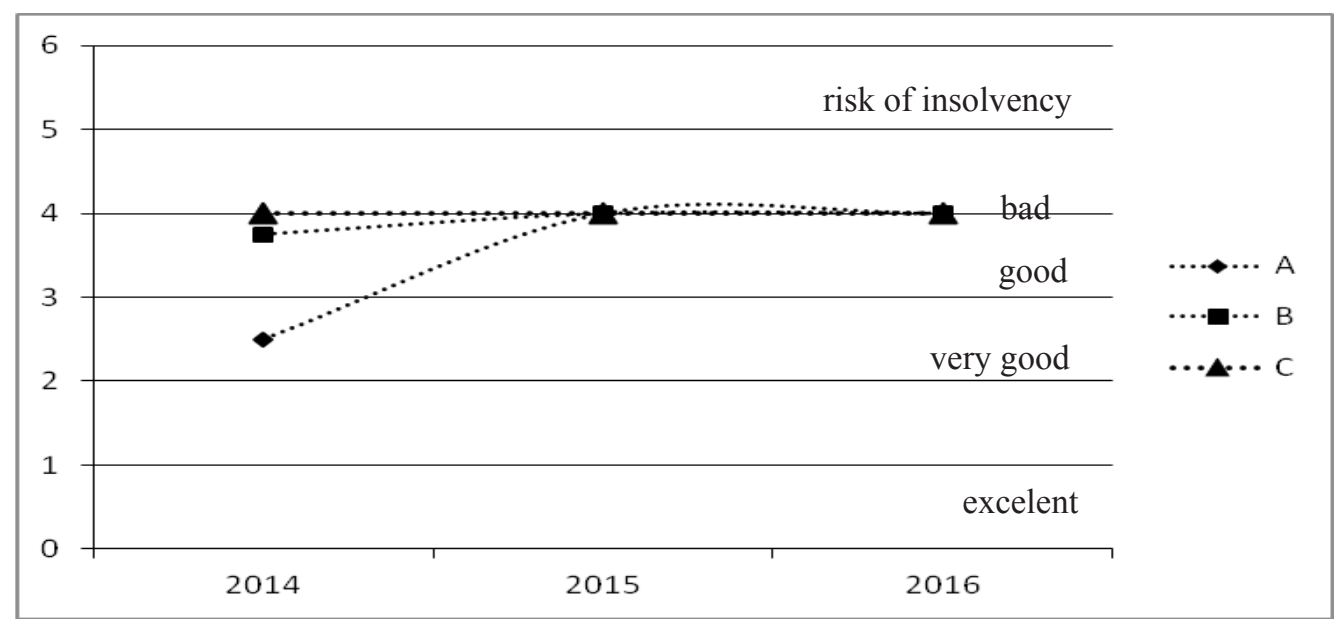


Further financial analysis was carried out using a balanced growth model. The analysis of this model indicates the extent to which the analyzed companies are able to generate cash flows in order to finance working capital in the situation of increased demand for working capital in the ongoing business and in the growth phase. The calculation of the results was based on the balance sheet and profit and loss accounts of the analyzed companies and are presented in Tables 7, 8 and 9.

Table 7. Components of a balanced growth model for company A

\begin{tabular}{|l|c|c|c|}
\hline E-components & $\mathbf{2 0 1 4}$ & $\mathbf{2 0 1 5}$ & $\mathbf{2 0 1 6}$ \\
\hline $\mathrm{R}=$ Retained Earnings/sales & 0.44 & 0.48 & 0.21 \\
\hline $\mathrm{G}=\left(\right.$ Sales $_{1} /$ Sales $\left._{2}\right)-1$ & -0.09 & -0.11 & 0.00 \\
\hline $\mathrm{T}=$ Current Assets/Sales & 0.67 & 0.75 & 0.81 \\
\hline $\mathrm{E}=\mathrm{R} / \mathrm{G}^{*} \mathrm{~T}$ & -7.01 & -5.85 & 0.00 \\
\hline
\end{tabular}

Company A has a noticeable negative growth rate in 2014 and 2015, while in 2016 it has a minimal growth registered only in the third decimal (0.001). Growth rates are negative due to a decrease in revenues in 2014 relative to 2015 and 2015 compared to 2016. Craft funds have growth under the pressure of negative growth rates leading to ever-increasing borrowing, while retained earnings are not enough to finance growth as an internal source of funding. As a result, borrowed funding sources are growing. The negative value $\mathrm{E}$, as well as the value 0 (zero), point to the problem of unbalanced growth and inadequate financing of this growth.

Table 8. Components of balanced growth model for company B

\begin{tabular}{|l|c|c|c|}
\hline E-components & $\mathbf{2 0 1 4}$ & $\mathbf{2 0 1 5}$ & $\mathbf{2 0 1 6}$ \\
\hline $\mathrm{R}=$ Retained Earnings/sales & 0.00 & 3.69 & 0.00 \\
\hline $\mathrm{G}=\left(\right.$ Sales $_{1} /$ Sales $\left._{2}\right)-1$ & -0.15 & -0.71 & 0.33 \\
\hline $\mathrm{T}=$ Current Assets/Sales & 4.57 & 1.00 & 0.71 \\
\hline $\mathrm{E}=\mathrm{R} / \mathrm{G}^{*} \mathrm{~T}$ & 0.00 & -5.16 & 0.00 \\
\hline
\end{tabular}

Company B has a marked growth rate measured (G) in 2014 and 2015, and in 2016 it has a positive growth rate of $33 \%$. Own sources of financing from retained earnings are very weak and in 2014 and 2016 they do not. In 2015, the self-financing rate of retained earnings is 3.69 but insufficient to finance growth. As a result, the growth of working capital in 2014 (4.57) was financed by a sharp increase in short-term loans, while internal sources of financing were of low capacity to finance growth. The value of E, which was 0 (zero) in 2016 and 2016, and in 2015 it was negative indicates serious financing problems as well as the lack of balanced growth. 
Table 9. Components of balanced growth model for company $\mathrm{C}$

\begin{tabular}{|c|c|c|c|}
\hline E-components & 2014 & 2015 & 2016 \\
\hline $\mathrm{R}=$ Retained Earnings/sales & 0.11 & 0.00 & 0.00 \\
\hline $\mathrm{G}=\left(\right.$ Sales $_{1} /$ Sales $\left._{0}\right)-1$ & -0.17 & -0.09 & -0.20 \\
\hline $\mathrm{T}=$ Current Assets/Sales & 2.06 & 0.97 & 0.75 \\
\hline $\mathrm{E}=\mathrm{R} / \mathrm{G}^{*} \mathrm{~T}$ & -0.31 & 0.00 & 0.00 \\
\hline
\end{tabular}

Company $\mathrm{C}$ has negative growth rates throughout the analyzed period. The rate of selffinancing of growth from retained earnings is 0 (zero) in 2015 and 2016, ie retained earnings in those years are not recorded. In 2014, the growth in business activities was financed from retained earnings at $11 \%$. The decline in working capital was caused primarily by the lack of own sources of financing for growth and the fall in short-term sources of financing. The negative value of $\mathrm{E}$ in 2014 as a value of 0 (zero) in 2015 and 2016 indicates that this company does not have a balanced growth.

\section{Conclusions}

On the road to joining and achieving full membership in the European Union (EU), Serbia must pass the transition process. In the transition process, a significant phase is privatization, which entails very profound changes in the economic system, and therefore in agriculture as an important branch of the Serbian economy. This process, according to many opinions and researches, did not meet the general expectations nor gave the expected result. Privatization in agriculture and the food industry took place without a clear plan and direction. In this process, the state obviously had a Laissezfaire approach that allowed privatization almost to the creation of a monopoly (dairy industry). The model of privatization by auction in most cases and the tender sale instead of recapitalization and retaining the core business did not make any positive progress. The companies remaining for privatization (on the website of the Ministry of Economy there are ten) do not make a significant financial or development base, with the exception of PKB Corporation, which is the only remaining agricultural conglomerate with development potential. The analysis of the financial position of the three companies to be privatized generally shows that their financial position is not good. Altman's test shows that company A and company $\mathrm{C}$ are in the gray zone, which means they are not completely resilient to bankruptcy while company B is in a distress zone, which has been shown by its status. Kralicek's Quick test showed that company A had a good financial position in 2014, but in 2015 and 2016 this position worsened to the category bad. The balanced growth factor for company A is negative only in 2016, where the value of this coefficient is negligible above zero, but far from the value of 1 which is a value that shows a balanced growth. According to Altman's test, company B is constantly in a distress zone, as confirmed by the Kralicek Quick Test, according to which this company is classified in the category of risk of insolvency. The balanced growth coefficient is far from the value of 1 (one), which points to the problem of growth imbalance. Company $\mathrm{C}$ is, according to the Altman test, constantly 
in the gray zone, which shows that it is not resilient to bankruptcy. The Kralicek Quick Test showed that this company is constantly in the category of bad and that it is close to the category of risk of insolvency. This company, as in previous cases, does not have a balanced growth. The overall assessment is that all three companies are not resilient to bankruptcy, they are in a poor financial position with an unbalanced growth. Privatization of these companies will be a problem, given that significant additional funds are needed for their consolidation, balancing the night flows and investing in development. PKB Corporation has a better chance of privatizing more because of the potential and relatively stable market, and less because of its financial position.

\section{Acknowledgements}

Paper is a part of the research at the projects no. 46001- Development and application of new and traditional technologies in the production of competitive food products with added value for European and global market- CREATE A FORTUNE OF SERBIAN ITS TREASURE, financed by the Ministry of Education, Science and Technological Development of the Republic of Serbia.

\section{Conflict of interests}

The authors declare no conflict of interest.

\section{References}

1. Alihodžić, A. (2013). Testing the Kralicek DF indicator application on the Belgrade Stock Exchange. Bankarstvo, 42(3), 70-95.

2. Altman, E. I. (1968). Financial ratios, discriminant analysis and the prediction of corporate bankruptcy. The journal of finance, 23(4), 589-609.

3. Altman, E.I. (1983) Corporate Financial Distress (ISBN: 0-471-08707-6), Wiley Inter Science, New York.

4. Altman, E. I. (2005). An emerging market credit scoring system for corporate bonds. Emerging markets review, 6(4), 311-323.

5. Begovic, S. V., Momcilovic, M., and Tomasevic, S. (2014). Credit rating of company - Z"'-Score model. Economic themes, 2014 52(2), 193-204. [in Serbian: Begović, S. V., Momčilović, M., i Tomašević, S. (2014). Ocena kreditnog boniteta preduzeća Z"-Score modelom. Ekonomske teme, 52(2), 193-204].

6. Bogavac-Cvetkovic, N., Ilic, B., and Milicevic, V. (2010). Globalization and competitiveness of the agrarian sector in Serbia. Economic Themes, 48(2). [in Serbian: Bogavac-Cvetković, N., Ilić, B., i Milićević, V. (2010). Globalizacija i konkurentnost agrarnog sektora srbije. Ekonomske teme, 48(2)].

7. Didenko, K., Meziels, J., and Voronova, I. (2012). Assessment of enterprises insolvency: challenges and opportunities. Economics and Management, 17(1), 69-76. 
8. Jakovčević, K., i Andrašević, J. (2011). Indicators of difficulties in the functioning of an industrial enterprise. Industry, 39(3), 175-192. [in Serbian: Indikatori poteškoća u funkcionisanju industrijskog preduzeća. Industrija, 39(3), 175-192].

9. Kozjak, S. K., Sestanj-Peric, T., and Besvir, B. (2014, January). Assessment of bankruptcy prediction models'applicability in Croatia, in An enterprise Odyssey leadership, innovation and development for responsible economy, 7th International Conference. International Conference Proceedings, June 4-7, Zadar Croatia, University of Zagreb, Faculty of Economics and Business, 543-554.

10. Kuběnka, M. (2016). The strictness of traditional indicators for creditworthiness measuring, in The 10th International Days of Statistics and Economics, Conference Proceedings, Prague, September 8-10, Libuše Macáková, Melandrium, 985-995.

11. Kuc, V. (2015). The analysis of financial structure in the largest enterprises in Serbia. Economics of the company, 63(7-8), 399-412. [in Serbian: Kuč, V. (2015). Analiza strukture finansiranja najvećih preduzeća u Srbiji. Ekonomika preduzeća, 63(7-8), 399-412].

12. Lončarević, S. (2015). Comparison to Kralicek DF Indicators and Altman Z-Score Model for Serbian Metal Industry. International Journal of Industrial Engineering and Management (IJIEM), 6(4), 199-204.

13. Muminović, S., Pavlović, V., and Cvijanović, J. M. (2011). Predictive ability of various bankruptcy prediction Z-score models for Serbian publicly listed companies. Industry, 39(3), 1-12.

14. Zdravković, A., Nikolić, D., Bradić-Martinović, A., (2010) Analysis of the privatization model in Serbia. In: The end of privatization, the consequences for economic development and unemployment in Serbia. Institute of Economic Sciences; Belgrade Banking Academy; Association of Independent Trade Unions of Serbia, Belgrade, pp. 278-287. Available at: http://ebooks.ien.bg.ac. rs/250/1/az 2010 01.pdf

15. Pejanović, R., Tica, N., (2005) Agrarian Problem in the Process of Transition of the Republic of Serbia, Yearbook of Scientific Works, Faculty of Agriculture, Novi Sad, 29 (1), 210-221. Retrieved from https://scindeks-clanci.ceon.rs/ data/pdf/0546-8264/2005/0546-82640501210P.pdf (06.05.2018)

16. Mihailovic, B., Cvijanovic, D., and Parausic, V. (2013). Analysis of the performance of primary agricultural production and food industry of Serbia. Agro-knowledge Journal, University of Banja Luka, Faculty of Agriculture 14(1), 77-85. [in Serbian: Mihailović, B., Cvijanović, D., i Paraušić, V. (2013). Analiza performansi primarne poljoprivredne proizvodnje i prehrambene industrije Srbije. Агрознање, 14(1), 77-85].

17. Jelic, S., and Jovanovic, T. (2010). Sensitive points of transition of agriculture. Sociological Review, XLIV (4), pp. 595-616. [in Serbian: Jelić, S., i Jovanović, 
T. (2010). Osetljive tačke tranzicije poljoprivrede. Sociološki pregled, Socijološko društvo Srbije, Beograd XLIV( 4), pp. 595-616].

18. Pejanovic, R. (2009). Development problems of agriculture of the Republic of Serbia. Agrieconomica 41-42(41-42), 5-23. [in Serbian: Pejanović, R. (2009). Razvojni problemi poljoprivrede Republike Srbije. Agroekonomika-. 41-42(41-42), 5-23].

19. Vehapi, S., and Sabotic, Z. (2015). The state and problems of Serbian agriculture. Economics of Agriculture, 62(1), 245.

20. Kapor, P. (2009). Foreign Direct Investment in Agriculture. Economics of Agriculture, 56 (2), 231-243. [in Serbian: Kapor, P. (2009). Strane direktne investicije u poljoprivredi. Ekonomika poljoprivrede 56(2), 231-243].

21. Anicic, J., Vukotic, S., and Krstic, S. (2016). The strategic aspects and results of agriculture development in Serbia in the transition period. Economics of Agriculture, 63(1), 175-187.

22. Pejanovic, R., Milanovic, M., and Cvijanovic, D. (2006). Transition (field) of the economy of the Republic of Serbia: domains, effects and limitations. Economics of Agriculture, 53 (4), 937-946. [in Serbian: Pejanović, R., Milanović, M., i Cvijanović, D. (2006). Tranzicija (poljo) privrede Republike Srbije: dometi, efekti i ograničenja. Ekonomika Poljoprivrede, 53(4), 937-946].

23. Đuričin, S., Beraha, I. (2014). Improving the financial performance of the agro-industry sector of the Republic of Serbia based on incentive development measures. Retrieved from http://ebooks.ien.bg.ac.rs/68/1/sdj_2014_01.pdf (05.05.2018).

24. Petrovic, P., Antevski, M., and Milanovic, M. (2006). Economic effects of the process of accession of the European Union to the export perspectives of agriculture in Serbia. Economics of Agriculture, 53 (2), 153-164. [in Serbian: Petrović, P., Antevski, M., i Milanović, M. (2006). Ekonomski efekti procesa pridruživanja Evropskoj Uniji na izvozne perspektive poljoprivrede Srbije. Ekonomika Poljoprivrede, 53(2), 153-164].

25. Walsh, C. (2003). Key management ratios: master the management metrics that drive and control your business (ISBN: 027366345 3). Financial Times/ Prentice Hall. London. 